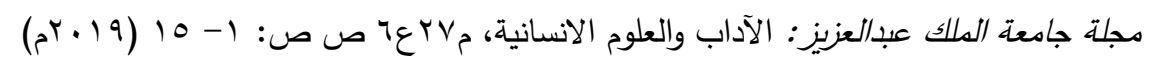

DOI:10.4197/Art.27-6.1

\title{
لغة الجسد في السنة النبوية (لغة الأيدي أنموذجا)
}

\author{
ريـم بنت خالد بن عبد الله السّقّاف \\ كلية الآداب والعلوم الإنسانية \\ جامعة الملك عبدالعزيز بجدة
}

مستخلص. الحمد لله رب العالمين، والصلاة والسلام على نبينا محمد، أما بعد:

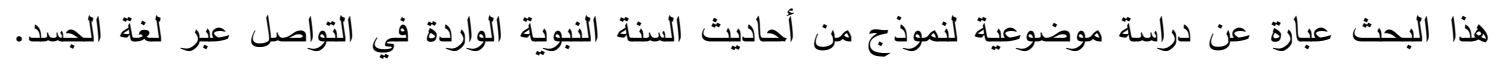

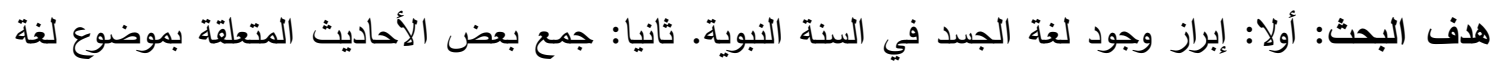

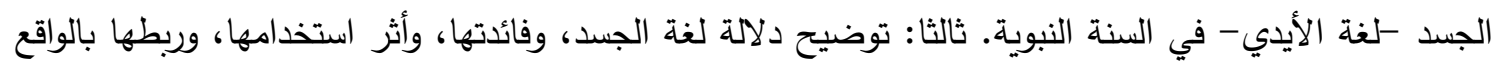
من خلال الرجوع إلى شروح الأحاديث وكتب مهارات الاتصال.

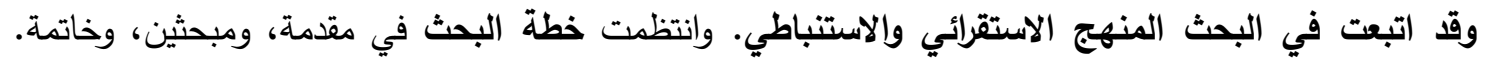

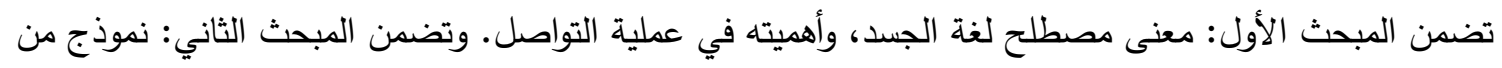

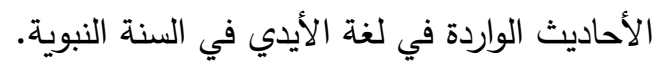

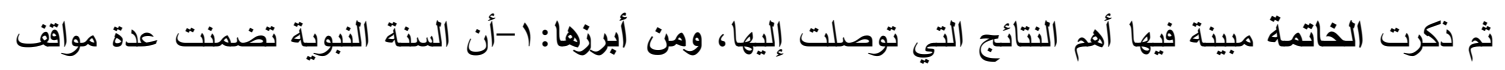

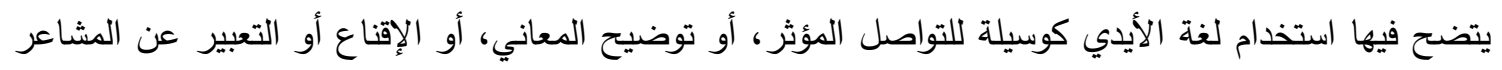

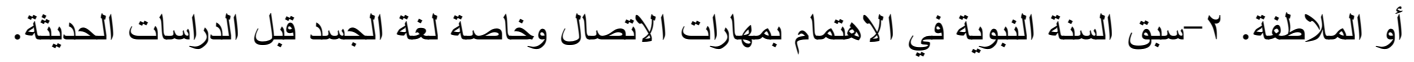

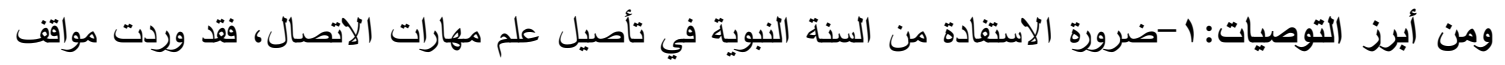

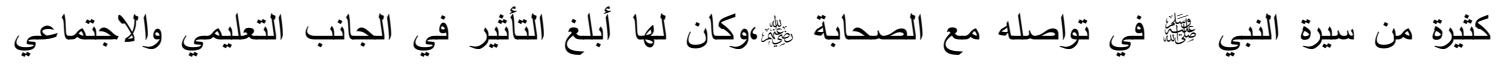

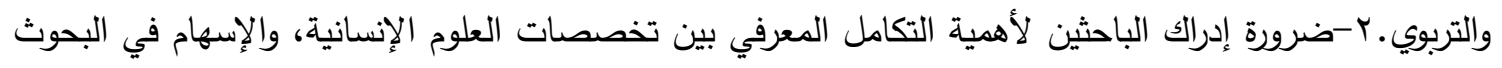
التي تجمع بين أكثر من تخصص؛ لما لذإلك من أثر في تأصيل المعرفة.

فإن الاتصال مع الآخرين من أهم الضرورات التي لا

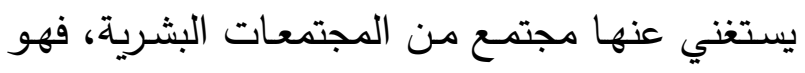
طريق العلاقات الناجحة، وتكوين الثقافات المختلفة. وهناك نوعان للاتصال: الاتصال اللفظي، والاتصال غير اللفظي أو ما يسمى: لغة الجسد.

\section{الُمقَدمة}

الحمد لله المنعم بالفضل الكبير ، والصـلاة و والسـلام

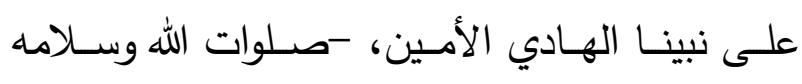
عليه- وعلى من تبعـه بإحسان إلى يوم الدين، أمسا بعد.. 
عبر لغـة الجسـ، كمـا أشـارت إلى ذلك البحـوث التربوية التي أجريت في هذا المجال.'

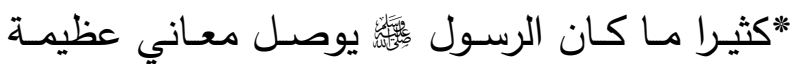
لأمتـهـه مسن خـلال لغـة الجســ سـواء في التربيـة أو

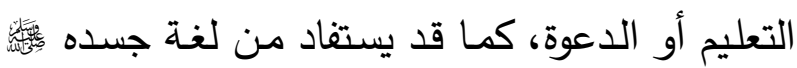
بيان لدلالة تشريعية كالكراهة أو الجواز أو التحريث. سبب اختيار الموضوع ا-الذي دعاني لاختيار الموضوع أني كثيرا ما كنت أجد استشهادًا بأهل الفن والمسرح أو السياسـة، عند قراءتي لموضوع لغة الجسد في كتب فنون التواصل وخاصـة الغربيـة منهـا، وكـان يتبـادر لـذهني حينـاذٍ

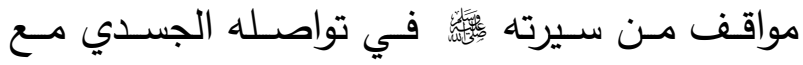
صحابته-رضوان الله عليهم- ومجتمعه من حوله في أرقى صور التواصل الاجتماعي والتربوي، وفي ذلك ما يغني عن الاستشهاد بحال غيره. ץ-الرغبـة في استقاء مهارات التواصل الناجح مـع

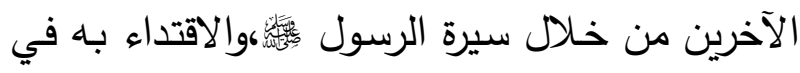
ذلك.

\section{أهداف البحث}

ا-إبراز وجود لغة الجسد في السنة النبوية. Y-جمـع بعض الأحاديث النبويـة المتعلقـة بموضـوع لغة الجسد -لغة الأيدي-في السنة النبوية.

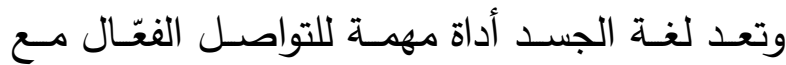
الآخــرين، وإيضـــاح المعــاني، وإيصــال الأفكــار والتعبير عن العواطف والأحاسيس. وقد تضـمنت الأحاديـث النبويـة عـدة مواقف تبـرز مهـارات التواصـل النـاجح مـع الآخـرين في الحيـاة الاجتماعيـة والـدعوة إلـى الله، تعدّ مثالاً يقتدي بـــ المسلم في سائر تعاملاته.

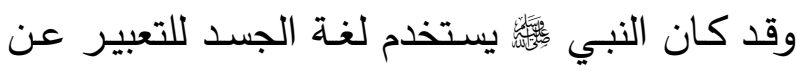
مشــاعره، أو لتوضــيح المعـاني، أو لبيــان دلالــــة تثـريعية كالكراهـة أو الجــواز ، وقـد كـان الصـحابة يفهــون هـذه الرسـائل ويـدركون معناهـا، وهـا يـدل على مدى استخدام لغة الجسد في السنة النبوية. وقد سعيت في هذا البحث لبيان جانب من جوانب لغـة الجســ في السـنة النبويـة، عـن طريـق عـرض الأحاديث التي يتضـح فيها استخدام لغة الأيدي في التواصل، مـع بيـان الدلالات التي دلت عليها. والله ولي التوفيق... وبـه أستعين.. أهمية الموضوع * لغة الجسد ذات أهمية كبيرة في عملية التواصل، إذ بها تكتمل العملية التواصلية لما تؤديه من دور فاعل في التعبير والإيضاح والتأثير ، وهي أقوى بخمس مرات من ذلك التأثير الذي تتركه الكلمات. ويشير العلمـاء إلىى أن 00\% مـن التواصـل يظهـر 
المطلب الأول: معنى لغة الجسد.

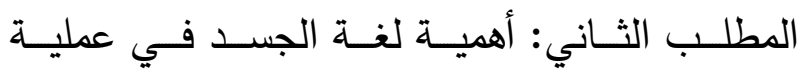
التواصل.

المبحث الثاني: لغة الأيدي في السنة النبويـة.وفيه

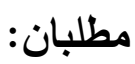
المطلـب الأول: الأحاديــث الــواردة فـــي الإثـــارة بالأيدي. المطلب الثاني: الأحاديث الواردة في اللمس بالأيدي. - الخاتمة: وتشمل أهم النتائج والتوصيات. منهج البحث

- عزو الاقتباسات إلى مراجعها في الهوامش

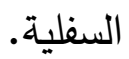

المبحث الأول: معنى مصطلح لغة الجسد، وأهميته في عملية التواصل. وفيه مطلبان: المطلب الأول: معنى لغة الجسد.

" لغة الجسد " مصطلح مركب من كلمتين هما: (لخ) و (الجسد اوبالرجوع إلى معاجم اللغة، نجد أن:

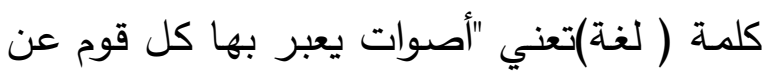

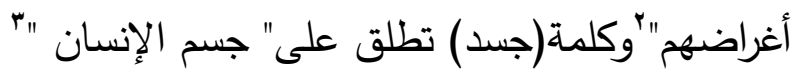
اصطلاحا:

يعد مصطلح "لغة الجسد" من المصطلحات الحديثة

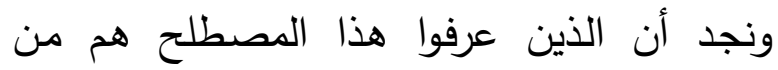

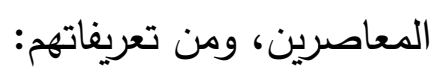

r القاموس المحيط،حمد بن يعقوب الفيروز آبادى، // اسبا ا، تحقيق:

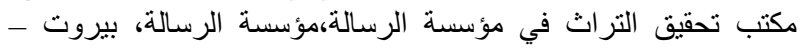

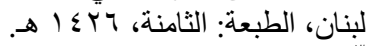

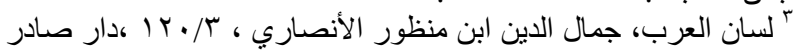

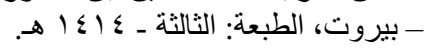

ب-توضيح دلالـة لغـة الجسـد، وذكر فائدتها، وأثر

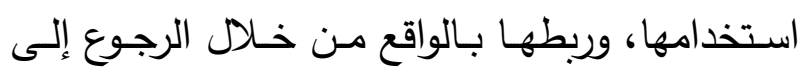
شروح الأحاديث وكتب مهارات الاتصال.

خطة البحث

قسمت البحث إلى : (مقدمة، ومبحثين، وخاتمة). - المقدمة : وتتضــن أهميـة البحث، وسـبب اختيـار الموضـوع، وخطة البحث، ومنهج البحث.

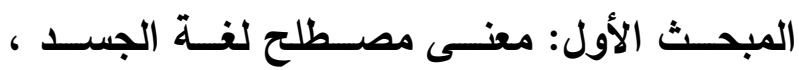
وأهميته في عملية التواصل. وفيه مطلبان:

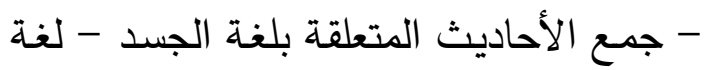

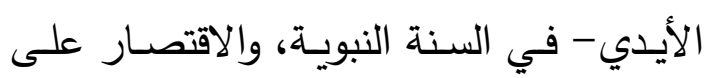

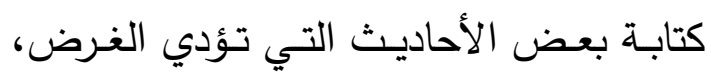
دون استقصاء. - تخريج الأحاديث النبويـة الواردة في البحث

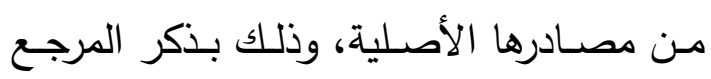
واسم المؤلف ثم الكتاب والباب الذي ورد فيه ثم رقم الحديث والجزء والصفحة. - نقل حكم العلماء على الحديث مـا لم يكن وفه ولهن في الصحيحين. - الاستعانة بالشـروح المختلفة لكتب الحديث

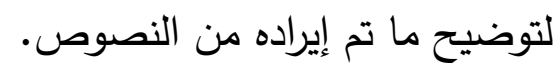
-بيان غريب الحديث من كتب اللغة وغريب

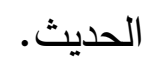
- الرجوع لكتب علم لغـة الجسـ وعلم النفس ومهارات الاتصال؛ لربط النصوص بالواقع. 
التواصل مـع الآخرين، أو التعبير عن المشـاعر ، أو بيان دلالة تشريعية كالجواز أو التحريم أو الكراهة. وسأقتصر في هذا البحث على ذكر لغة الأيدي الواردة في السنة النبوية.

المطلـب الثـاني: أهميــة لغـة الجســـ في عمليـة التواصل. لغــة الجســـ لهـا دور فاعـل فـي عمليـة التواصـل، ومازال العلماء يؤكدون على أهميتها، وتقوقها على الاتصال اللفظي، ومن ذلك ما يلي: يقول الدكتور محمد بني يونس: "لغة الجسد من الوسائل التي تحقق الكثير من التجاوب بين الناس، وهي أقوى بخمس مرات من ذلك التأثير الذي تتركه الكلمات.

فقد أثبتت الدراسات الحديثة أن ما يقارب من 00\% من الأهداف التي يطمح المرسل إلى تحقيقها، يصل إليها عن طريق الإيماءات والحركات بينما تحقق باقي العناصر النسبة المتبقية أي بنسبة هـ؛ v."

لائويد هذا القول د.نضال أبو عياش حيث يقول" يقتصر نقل الأفكار والمعاني على استخدام الكلمات المقرويءة أو المنطوقة، بل هنالك وسائل يتم من خلالها الاتصال، وتكاد تكون أكثر من تلك التي نتبادلها من خلال الاتصال اللفظي "

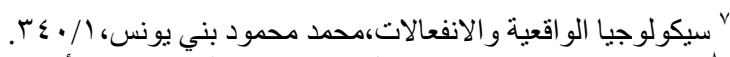

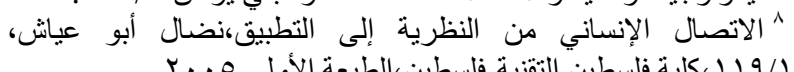

*"نوع من التواصل غير الثفهي". "*إثارات وإيماءات جسدية ترسل رسالات محددة في مواقف وظروف مختلفة، تظهر للك المشاعر الدفينة وتخرجها للسطح، فتصل من خلالها معلومات أو موطرون أفكار عن الشخص الآخر " . " " رسائل شعورية أو لا شعورية، تتطلق من جسد الاحر الإنسان لإيصال مفاهيم أو رسائل معينة للآخر"." من خلال هذه التعريفات يمكن تعريف لغة الجسد بأنها: إشارات وإيماءات جسدية ترسل في مواقف هذه وظروف مختلفـة، للتعبير عن المعـاني والأفكار والمشـاعر والسـوك وإيصـالها للآخر • وهي تمثل جانب من جوانب الاتصال غير اللفظي. ونلاحظ في التعريفات السابقة أنها تشمل لغة الجسد المقصودة وغير المقصودة. والمراد في هذا البحث الإشـارات والإيمـاءات الجسـية المقصسودة، التي تـؤثر ايجابيًا في عمليـة التواصل. - اصل

وبذلك يمكن تعريف "لغة الجسد في السنة النبويـة" بأنها: الإشارات والإيماءات الجسدية التي وردت في السنة النبويـة؛ وكان لها أثراً إيجابيا يستفاد منـه في

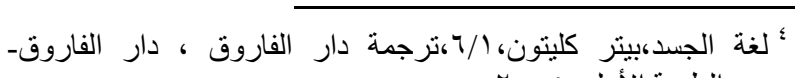

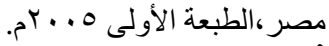

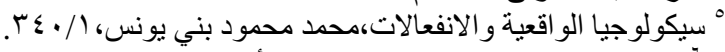

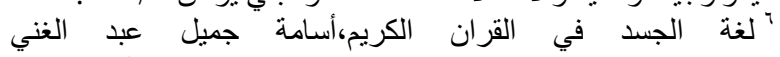

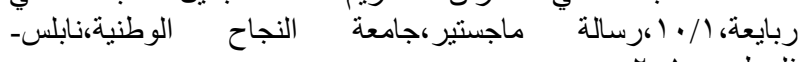


العلاقـات بـين أفراد المجتمـع، والمسـاهمة في نشـر الخير والفضيلة، والدعوة إلى الله بالحكمة والموعظة الحسنة، وتحقيق المعاملة الحسنة.

\section{المبحث الثاني: لغة الأيدي في السنة النبوية.}

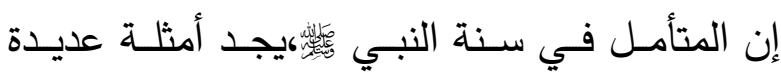
يتضح فيها استخدام لغة الجسد والاهتمام بها، وذلك من قبل أن يتوصل العلمـاء إلى كونـه فن جديد من فنون الاتصال و أن لهم السبق في الإشارة إليه. حيث أشار الباحثون في هذا المجال إلى أن البحث في علم لغـة الجسـ لم يبدأ على نطاق واسـع حتى الخمسينات من القرن العشرين. '1 وقد تضمنت السنة النبويـة الكثير من المواقف التي يتضح فيها استخدام لغة الأيدي كوسيلة للتواصل أو توضيح المعاني، أو التعبير عن المشاعر.

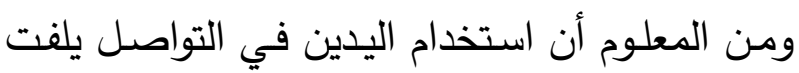
الانتبـاه، ويـؤثر في عمليـة التواصل، ويسـاعد على الاحتفاظ بكثير من المعلومـات، كمـا قد يغني عن الكلام . النام

وسوف أوضـح نماذج من هذه الأحاديث من خـلال مطلبين: المطاـبـ الأول - الأحاديــث الـــاردة فــي الإثــارة بالأيدي:

' يُنظر"تحتاج أن تعرف لغة الجسد"،كارولين بوييز،/1/1/، مكتبة

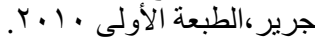

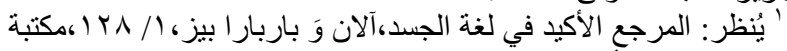

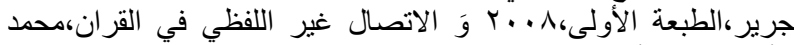

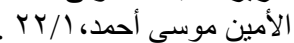

وتتضح أهمية لغة الجسد من خلال معرفة ما يلي: ا- لغة الجسد قد تكون مفسرة للألفاظ، كأن تستعمل الإشــارات، والإيمــاءات، والحركـات، أو الصــور ؛ لتقريب المعـاني وإيضـاح الألفـاظ، بمـا يسـاعد على لـى نجاح عملية الاتصال. Y-لغـــة الجســد مكملــة ومؤكــدة للألفــاظ، مثـل: الابتسامة بعد أن تطلب شيئاً من شخص، أو مثل أن تضرب المنضدة بعد أن تتفوه بعبارة ما. r- لغة الجسد تساهم في تنظيم وربط الاتصال بين المشاركين، مثال ذلك :حركة الرأس والعينين، أو إعطاء إشارة للشخص ليكمل الحديث أو يتوقف عنه. ع-يمكن للغة الجسد أن تكون بديلا عن الكلام، فتعبيرات الوجه أحيانا تغني عن الكلام. 0 - يُعبر الجسد عن معلومات وجدانية، يمكن من خلالها التعبير عن الحب،والبغض،والكره، والاهتمام، والثقة، والرغبة، والدهشة، والموافقة. ج-لغــة الجســ تتسـم بالمصـداقية في التعبيـر عـن 9. المشاعر ، والأفكار ، والكلام نستتج مما سبق أن لغة الجسد لها تأثير في الحوار وإيصال المعاني والأفكار بصورة تفوق تأثير الكلام المنطوق. لذلك حريّ بالمسلم أن يهتم بمعرفة مهارات وأسـاليب التواصـل النـاجح، لمـاـ لـذلك مـن أثـر فـي تقويــة

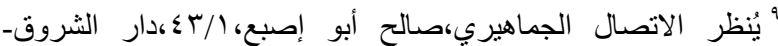

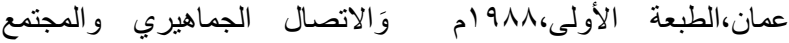

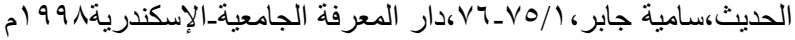

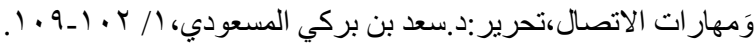


إلى أصل واحد، وتجمعهم أخوة النسب إلى آدم ونوح

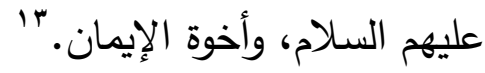

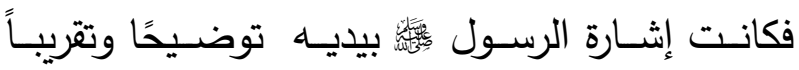
لبعنى في نفس السامع.

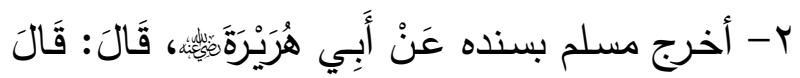

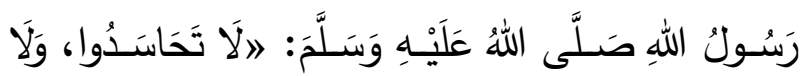

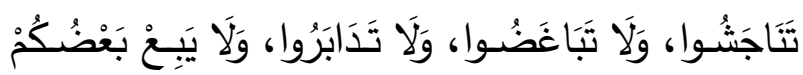

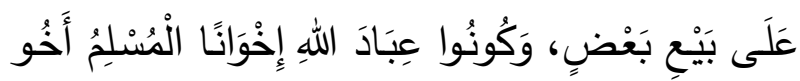

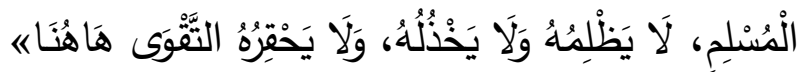

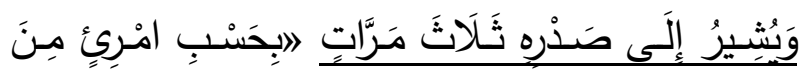

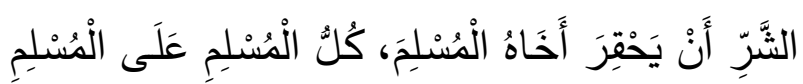

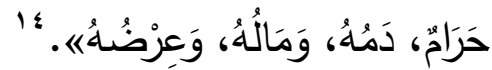

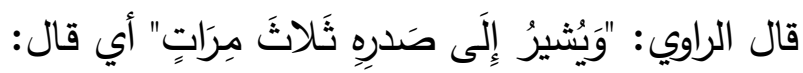
التقوى هاهنا، التقوى هاهنا، التقوى هاهنا،

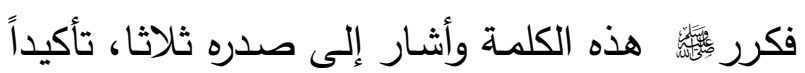
لكون القلب هو المدبر للأعضاء وأن عددة التقوى التهائ ما يحل في القلب من خشية الله ومراقبته وإخلاص

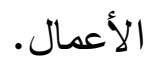

ويستفاد من ذلك: "أن الفعل قد يؤثر أكثر من القول

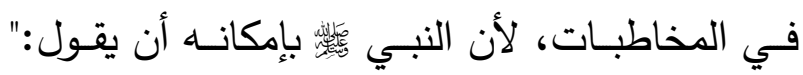
التقوى في القلب"، لكنه قال: "التقوى هاهنا وأشـار

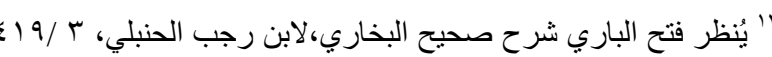

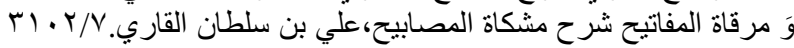

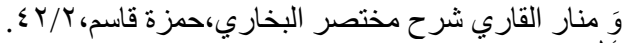

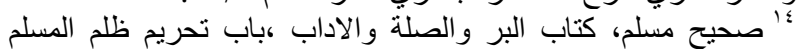

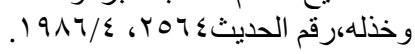

سبق الرسول لعاء علماء التربية في إدراك أثر استخدام

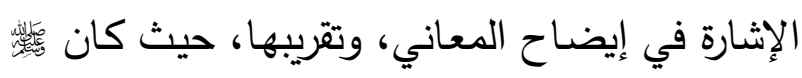

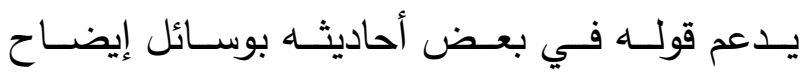

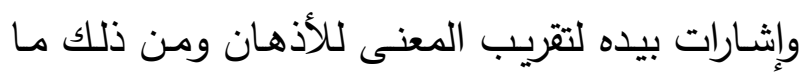

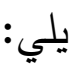

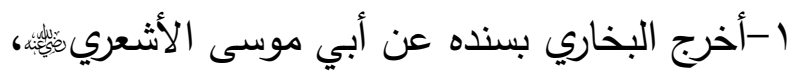

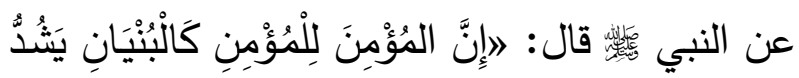

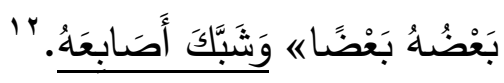

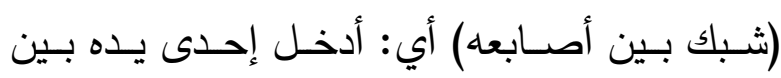

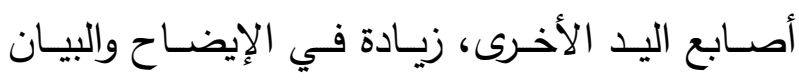

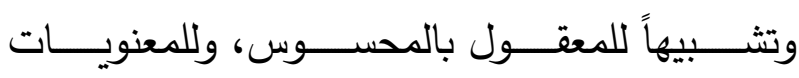
بالمحسوسات. أي يشد بعضه بعضاً مثل هذا الثد، فالغرض من تشبيك أصابعه التمثيل وتصوير المعنى في النفس لئس

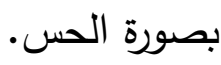

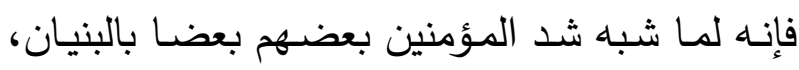

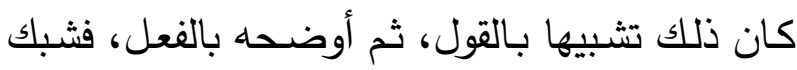
أصابعه بعضها في بعض؛ ليتأكد بذلك المثال الذي باني ضربه لهم بقوله، ويزداد بيانا وظهورا. ويفهم من تثبيكه: أن تعاضد المؤونين بينهم كتثبيك الأصابع بعضها في بعض، فكما أن أصابع اليدين

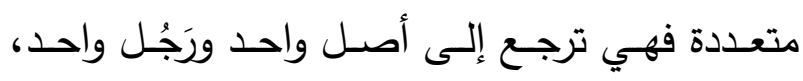
فكذلك المؤمنون وإن تعددت أشخاصهم فهم يرجعون

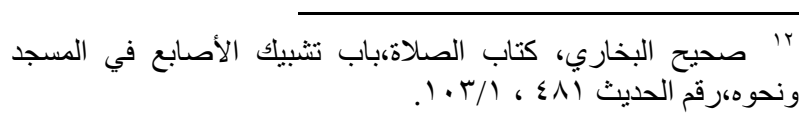


"حلق بإصبعه الإبهام والتي تليها": أي جعل الإصبع

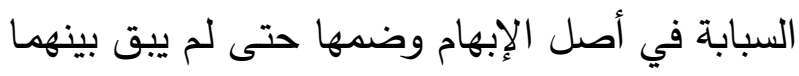
إلا خلل يسير ، والمعنى: فتح اليوم من سد يأجوج

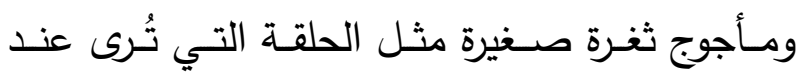
إيصال طرف السبابة بأصل الإبهام، أي أنه لم يبق تُّل لمجيء الثر إلا اليسير من الزمن.

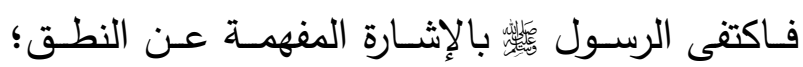
للتوضيح والتثثيل وتقريب الصورة في الأذهان. وقد أشـارت الدراسـات الحديثة في هذا المجال أن إيماءات اليدين أكثر فعالية في تجسيد الأشكال من النات الكلمات، حيث أن هناك كلمات قليلة تجسد الأشكال الهندسية وذلك لنقص الترميز اللفظي في بعض هض

$$
\text { المجالات. r. }
$$

\section{المطلـب الثـاني - الأحاديـث الــاردة في اللمس} بالأيدي: ومن الأحاديث التي أشارت إلى ذلك ما يلي:

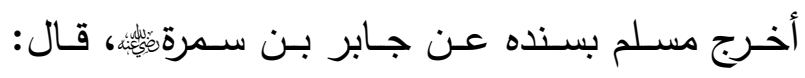

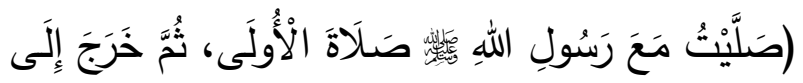

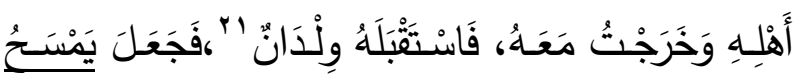

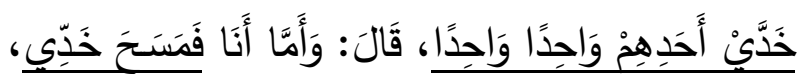

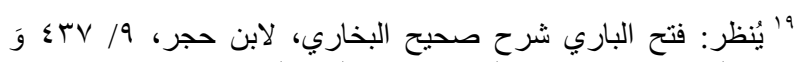

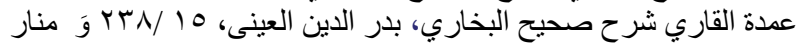

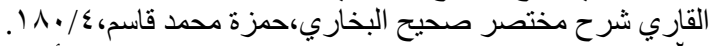

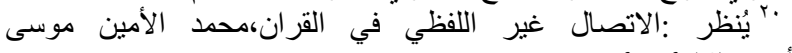

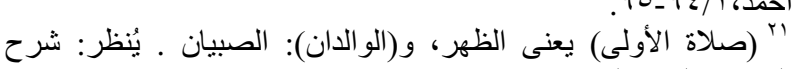

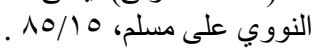

إلىى صـدره"، لأن المخاطـب يتصـور هـذه الصـورة ويتخيلها في ذهنه". وهـذا مُلاحـظ فـي ثبــوت المعلومــة فـي الــذهن واستحضارها عندما ترتبط بإشارة أو حركة مصاحبة أكثر من الكلام المجرد عن ذلك.

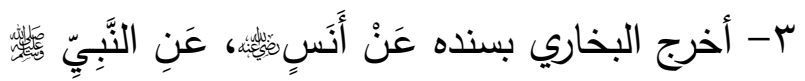

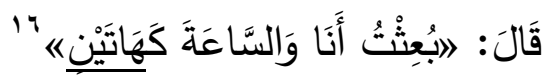
اكتفــى النبــي

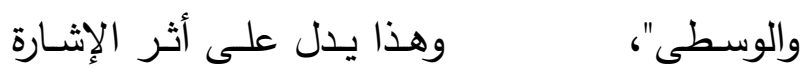
وقوتها في توضيح المعنى مما يغني عن الكلام . وفي قولـه (كهـاتين): " تمثيـل لمقاربتها،وأنــه لـيس لـيس بينهمــا إصـبع أخـرى كمـا أنــه لا نبـي بينــه وبـين الساعة، ويحتمل أنه لتقريب ما بينهما من المدة وأن الن التفاوت بينهما كنسبة التفاوت بين الإصبعين تقربيا V تحديدا". ع-أخرج البخاري بسنده عن زينب بنت جحش رضي

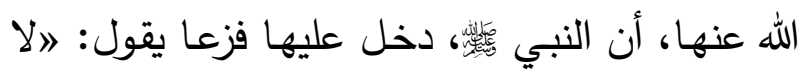
إله إلا الله، ويل للعرب من شر قد اقترب، فتح اليوم مـن ردم يـأجوج ومـأجوج مثل هذهه وحلق بإصـبعه

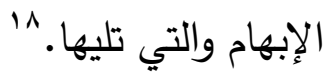

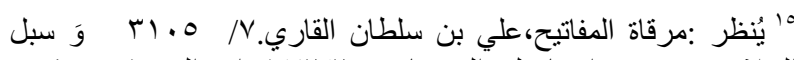

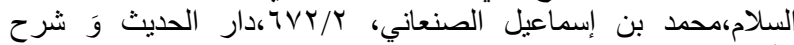

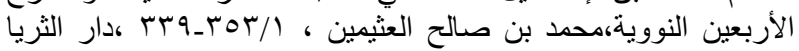

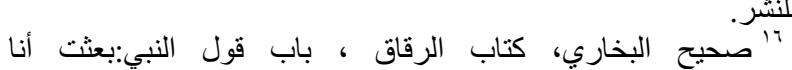

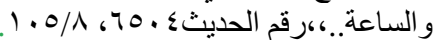

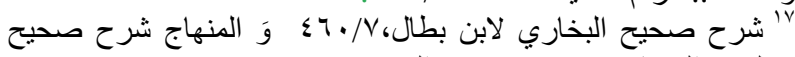

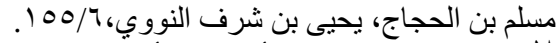

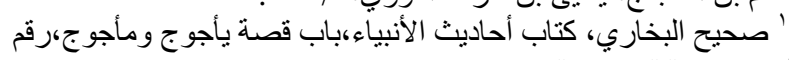

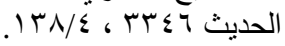


قياساً على الطفل الذي لا يحصل على لمس والديه. ؛ ومن ذلك:

حث النبي

والحنان والمواساة وذلك بالمسح على رأسه:

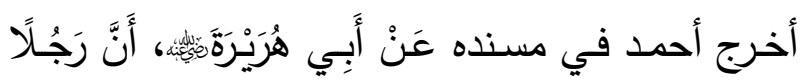

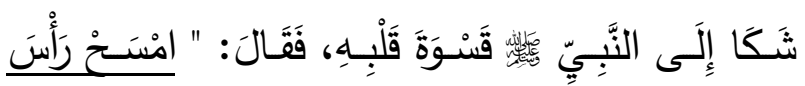

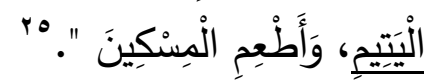
جعل النبـي مسـح رأس اليتيم عطفـا وحنـوا : سبيلا لمعالجة قسوة القلب المبعدة عن الرب ،وفيه أن من ابتلي بـداء مـن الأخـلاق الذميمـة يكـون تداركـهـ بمـا يضـاده مـن الـدواء فـالتكبر يـداوى بالتواضـع وقسـوة القلب بالتعطف والرقة. قـال الطيبـي: مسـح رأس اليتـيم كنايـة عـن الثـفقة والتلطف إليه.

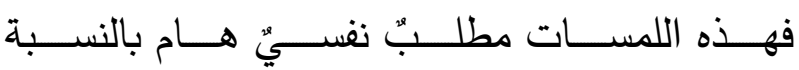

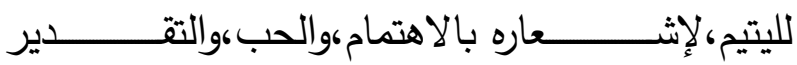
،والرعايـة،وتعويض الحنـان الذي حُرِمـه،وذلك بمسـح رأسها والإحسان إليه. - اليه.

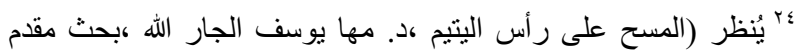

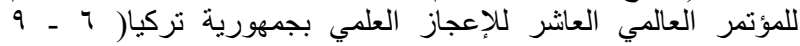

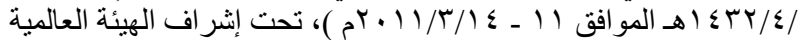
لكلإعجاز العلمي في القرآن و السنة.

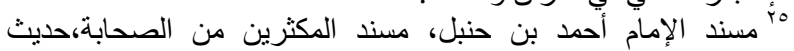

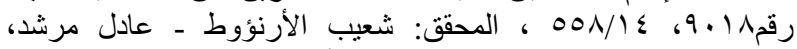

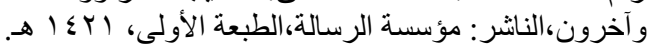

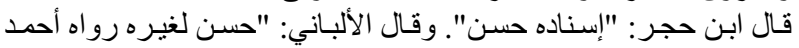

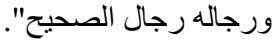

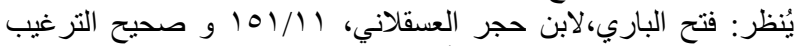

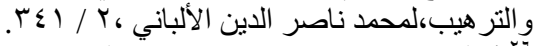

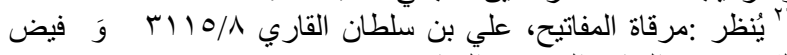

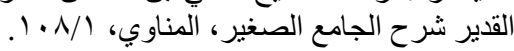

قَالَ: فَوَجَذْتُ لِيَدِهِ بَرْدًا أَوْ رِيحًا كَأَنََّـا أَخْرَجَهَا مِنْ

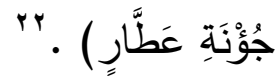

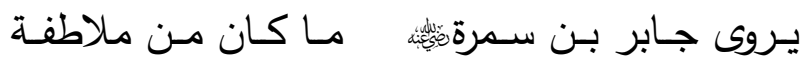

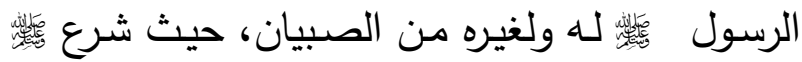
بمسح وجوههم بيديه الكريمتين.

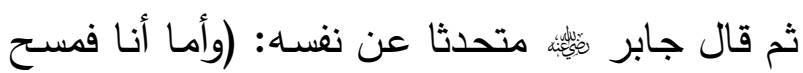
خديّ فوجدت ليده بردا) أي: راحة ،(أو ريحـا) أي:

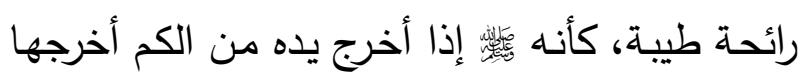
من جُوْنَةِة العطار التي يعد فيها الطيب ويحرز . وفي تعبير جابر بذلك دلالة على أثر تلك اللمسات عليـه، وأنها كانـت مـن قلبـه بمكان، حيث أنـه لازال يتـذكر ويصـف مـا وجـــ -مـن بـرد ورائحسة يديـهـ الكريمتين - وصفاً يستثعر معه السامع ذلك. وفي مسحه للأطفال وتودده وتواضعه لهم . وقد أثـارت الدراسـات الحديثة حـول التواصـل عبـر اللمس إلى أثره في النمو السليم العام للطفل نفسياً، وعاطفياً، وبدنياً التهي وفي دراسـة للباحث (اكريمـان) عـام الو 99 ام: وجد أن الطفل الذي يحصل على مسح جيد من قبل أفراد أسرته يكـون أقل عدوانيـة وأقـل مشـاكل في المدرسـة والبيـت

rrrr

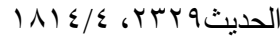

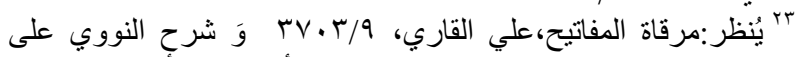

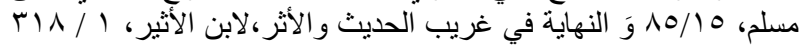




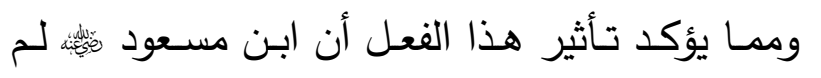

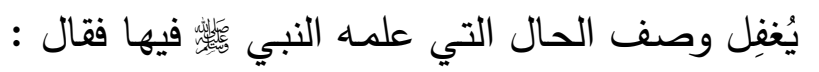
(وكفي بين كفيه) مما يدل على استحسانه و حفاوته بذلك.

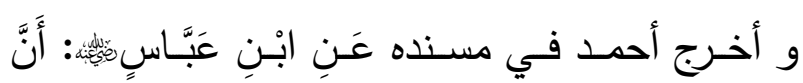
رَسُسولَ اللهِهِ

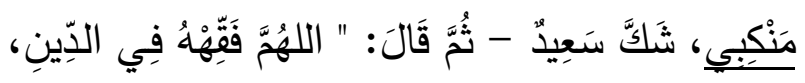

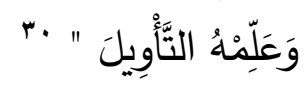

يتضح من الحديثين السابقين أن من وسائل التعليم

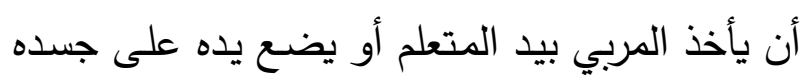

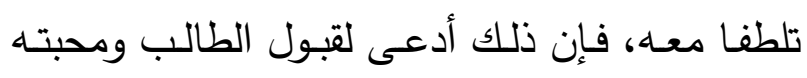

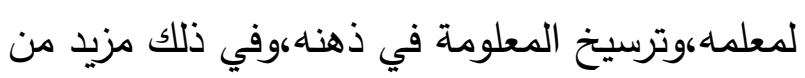
العناية والاهتمام. كما يدل على تخصيص من تميز من الطلبة بمزيد

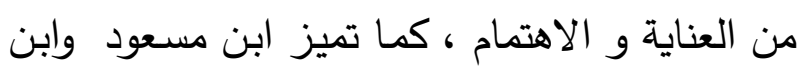
عباس -رضي الله عنهما- من بين الصحابة.

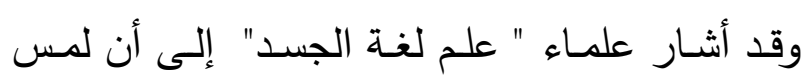
الشخص أثناء التحدث إليه يساعد في توجيه انتباهـ

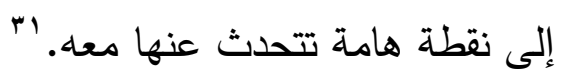

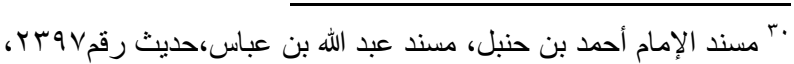

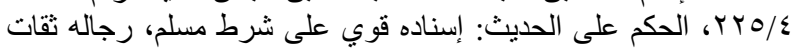

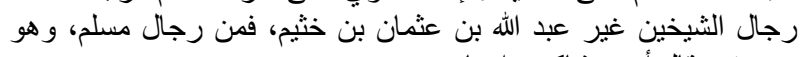
صدوق،وقال أحمد شاكر : إسناده صحيح.

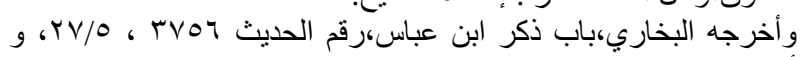

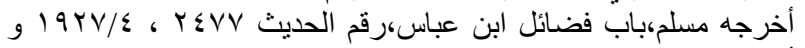

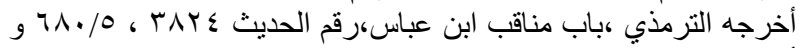

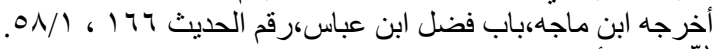

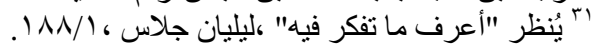

وقد أشار العلماء إلى وجه الإعجاز في ذلك: بأن الماسح عندما يضع يده على رأس اليتيم يحدث

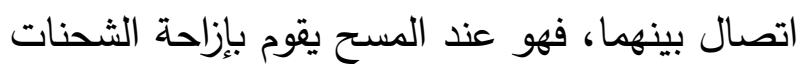
السلبية التي يحملها ذهن اليتيم، وبتكرار تلك العملية

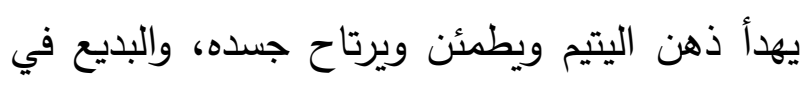
تلك العملية أنه يحدث لكلا الشخصين (الماسح واليتيم) علاج عضوي من جراء تلك العملية. وبذلك يتضح أثر المسح على رأس اليتيم في إثعاره بالاهتمام والطمأنينة،والملاطفة والمودة.

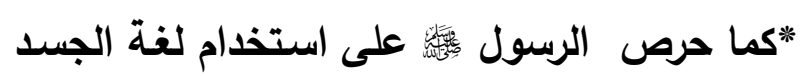
: أثناء تعليمه صحابته

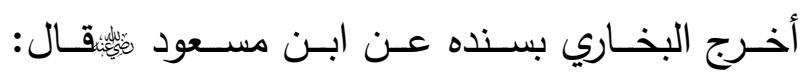

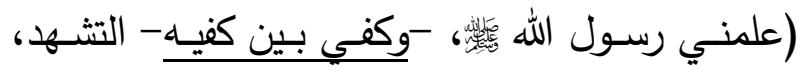

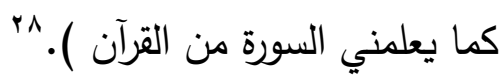
استخدم لابن مسعود oِ فئه فعلمه التشهد آخذاً بيديه.

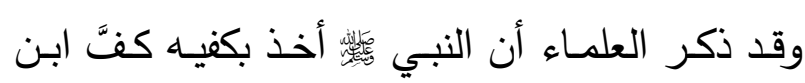

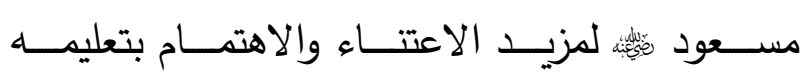
التشهد

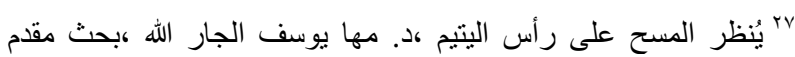

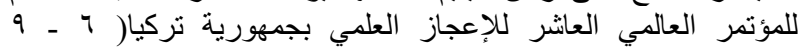

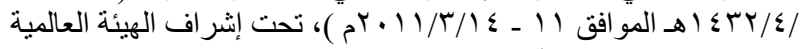
لمالِإعجاز العلمي في القرآن و السنة.

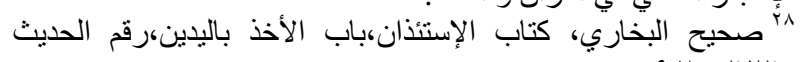

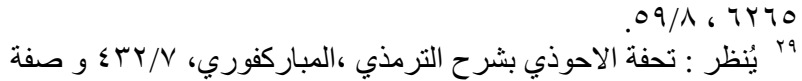

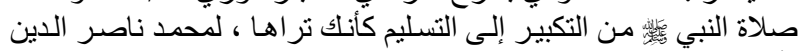

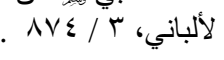


الرسول "أس عازماً على عدم الالتفات إلى الزنا بعد ذلك. فكانت تلك اللمسات العاطفية من الرسول

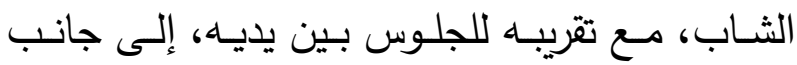

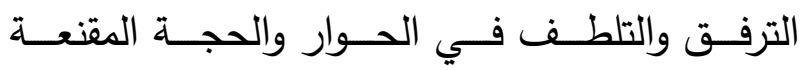
كالمفاتيح التي تُقتح بها مغاليق القلوب.

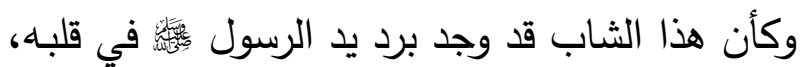

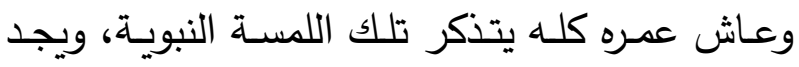

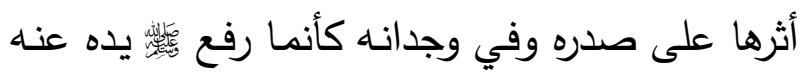
تلك الساعة. فحري بالمسلم أن يسلك منهج الرسول في النصح والإرشاد ومعالجة الأخطاء. "ومن لغة الأيدي الأخذ بيد المصافح:

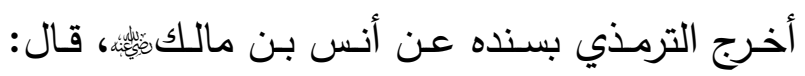

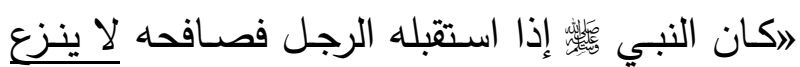

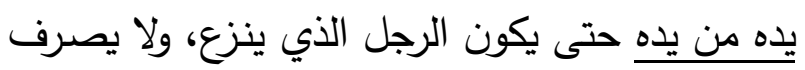

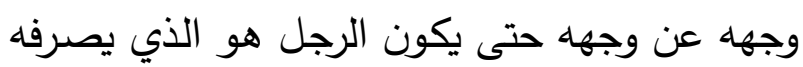

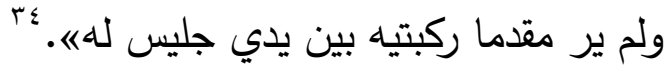

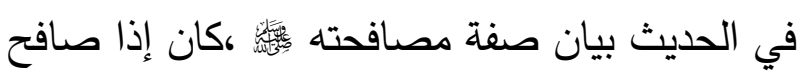
الرجل (لم ينزع) : أي لم يخلص ولم يفك يده حتى

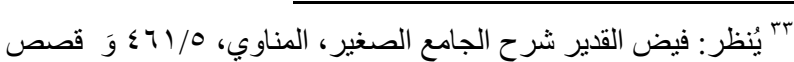

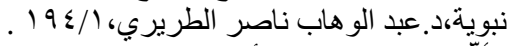

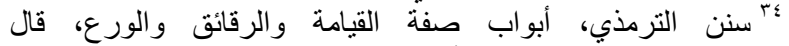

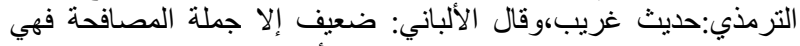

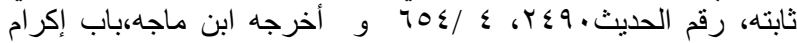

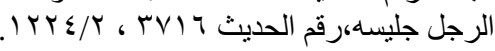

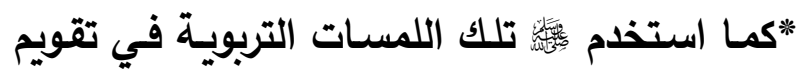
ومعالجة الأخطاء :

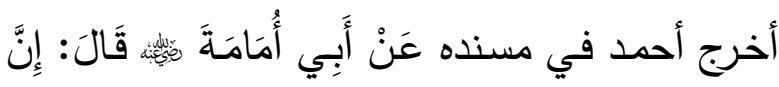

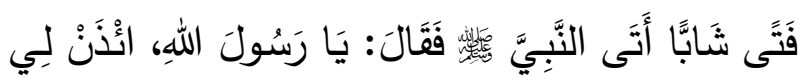

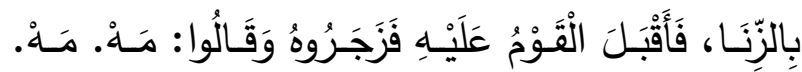

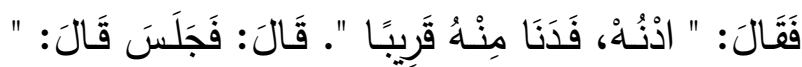

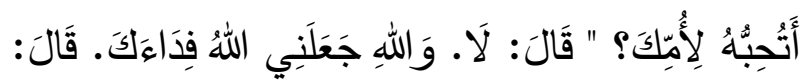

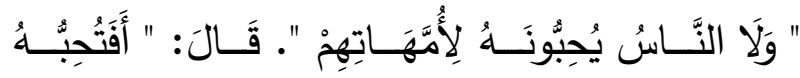

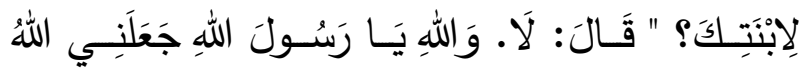

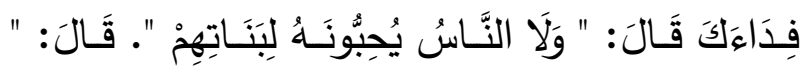

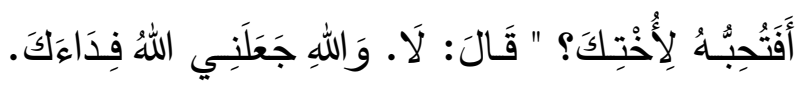

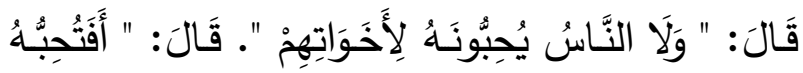

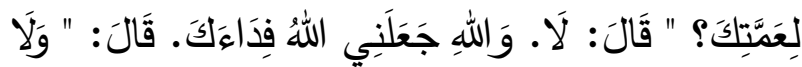

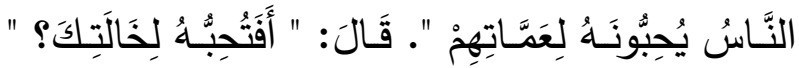

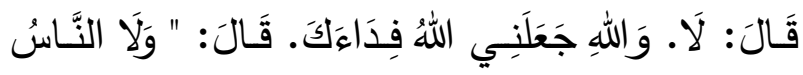

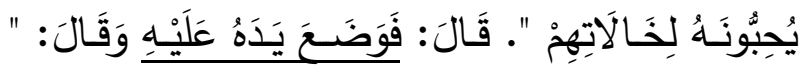

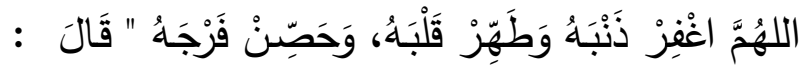

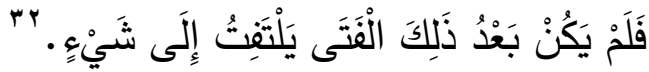

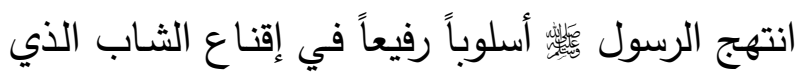
جاء يستأذنه في الزنا، حيث قربـه منـه قائلا: (ادنُ) حتى جلس بين يديه ،ثم لقيه بهذا الرفق العجيب

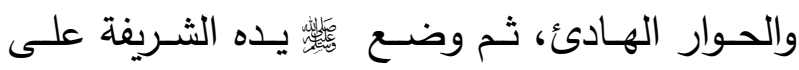
صدره ودعا لـه، حتى قام ذلك الفتى مقتنعاً بكلام

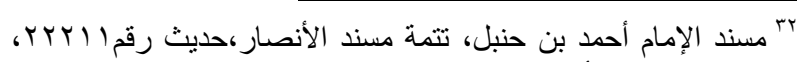

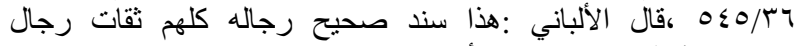

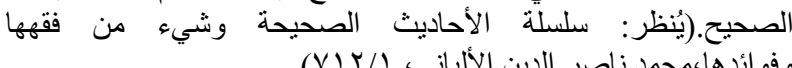
وفو ائدها،محمد ناصر الدين الألباني، (VIY/T). 
"يعد مصطلح "لغة الجسد "من المصطلحات"

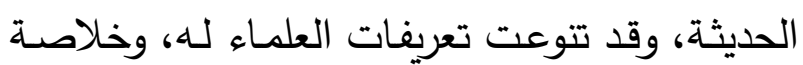
ذلك أنها : إشارات وإيماءات جسدية ترسل في نياء مواقف وظروف مختلفة، للتعبير عن المعـاني والأفكار و المشاعر والسلوك وإيصالها للآخر . * المراد بـ "لغة الجسد في السنة النبوية": الإشارات والإيماءات الجسدية التي وردت في السنة النبويـة

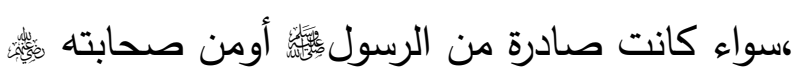

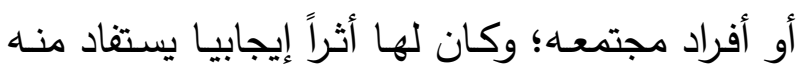

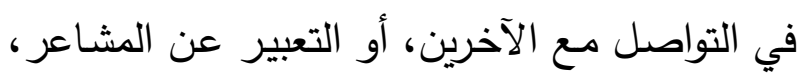
أو بيان دلالة تشريعية.

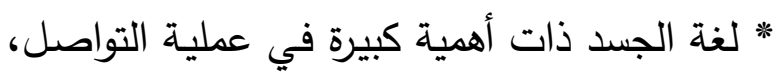
لما تؤديه من دور كبير في الإفهام والإيضاح ،والمصداقية والتأثير ·

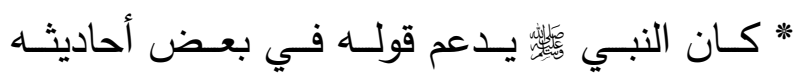

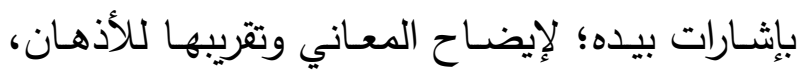

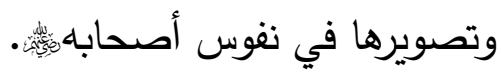
"وردت عدة أحاديث توضح أثر التواصل الإيجابي

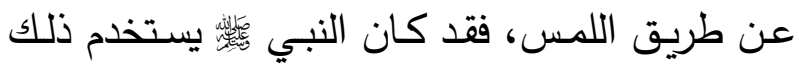

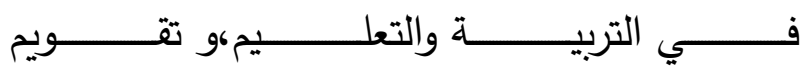

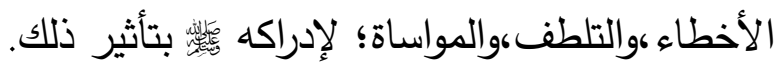
*سبق السنة النبويـة في الاهتمام بمهارات الاتصـال وخاصة لغة الجسد قبل الدراسات الحديثة.
يكون الرجل هو الذي ينزع يده، إكراما لصاحبه فلا يبدأ بالمفارقة عنه.

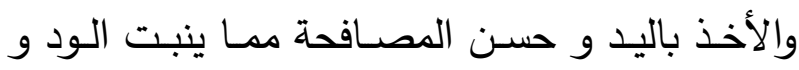
المحبة بين المتصافحين، وفيه تقوية لأواصر العلاقة

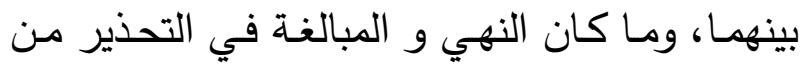

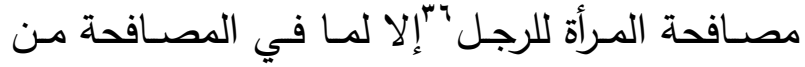
الأثر الكبير الذي تتركه في النفس، فكان النهي لدرء الفتنة.

مـن خـلال الأحاديث السـابقة يتضـح أثر الاتصــال

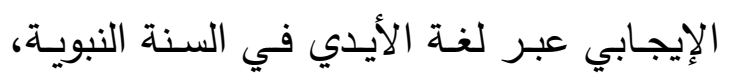

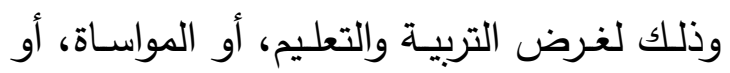
تقويم الأخطاء، أو التلطف و الإيناس، والتعبير

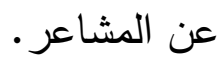

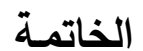

الحمـــ لله الـــي بنعمتـه تـتم الصــالحات والصـلاة والسـلام على خاتم الأنبياء والمرسلين نبينـا محمد لهد وعلى الله وصحبه أجمعين.. من خلال دراستي لهذا الموضوع يمكن استنتاج مـا يلي:

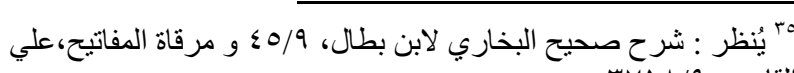

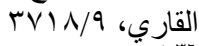

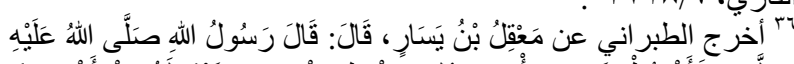

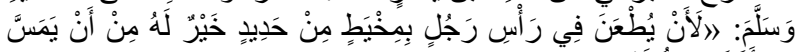

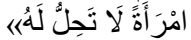
المعجم الكبير،سليمان بن أحمد الثامي الطبراني.r، / / بآك،المحقق:

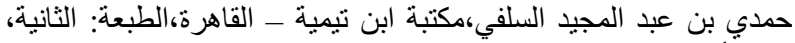

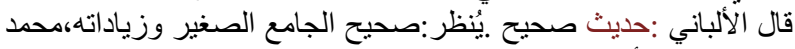

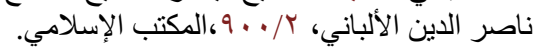




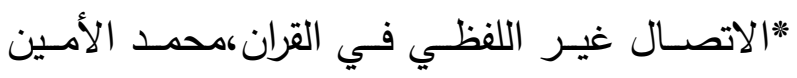

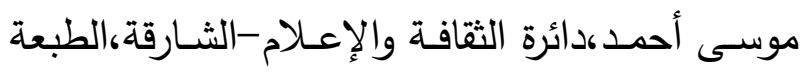

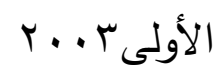

*الاتصال الإنساني من النظرية إلى التطبيق،نضال

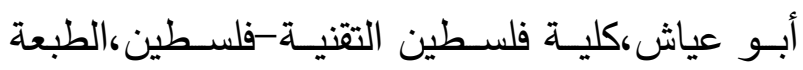

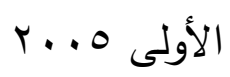

*الاتصـــال الجماهيري،صــــالح أبــو إصــبع،دار

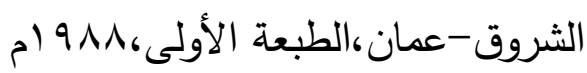

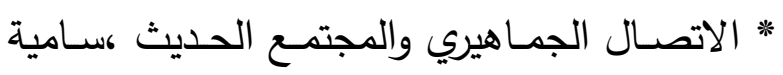

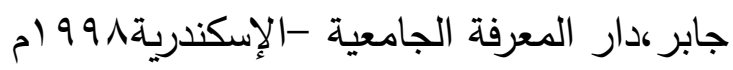
*أعرف مـا تفكر فيـه ،ليليان جـلاس ،مكتبـة جرير

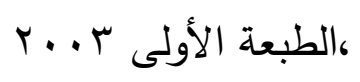

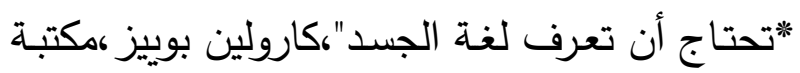

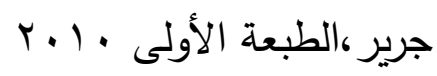

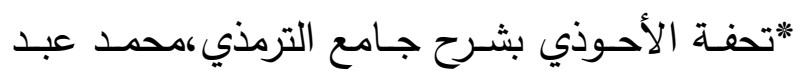

الرحمن المباركفورى،دار الكتب العلمية - بيروت . * سبل السـلام،محمد بـن إسـماعيل الصنـعاني، دار الحديث.

"سلسـلة الأحاديث الصـحيحة ،محمد ناصـر الدين

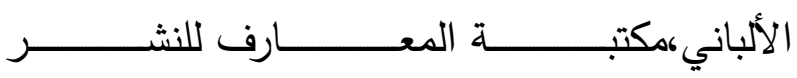

$$
\text { والتوزيع،الرياض،الطبعة: الأولى. }
$$

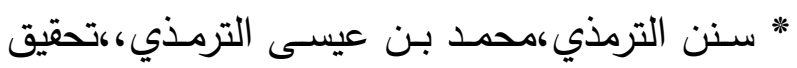

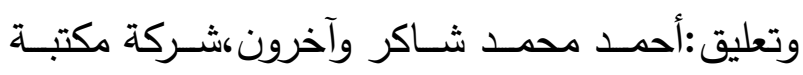
ومطبعـة مصطفى البابي الحلبي - مصـر ،الطبعة:

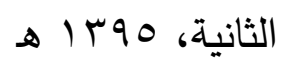

$$
\text { ومن أهم التوصيات: }
$$

ا-ضـرورة الاستفادة مـن السـنة النبويـة في تأصيل وتعزيـز مهارات الاتصـال، فقد وردت مواقف كثيرة

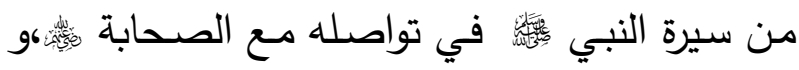
كان لها أبلغ التأثير في الجانب التعليمي والاجتماعي و التربوي • ץ-ضـرورة إدراك الباحثين لأهميـة التكامل المعرفي

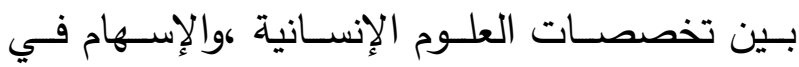
البحوث التي تجمع بين أكثر من تخصص؛ لما لذلك الأس من أثر في تأصيل المعرفة. r- حريّ بالمسلم أن يهتم بمهارات وأساليب التواصل

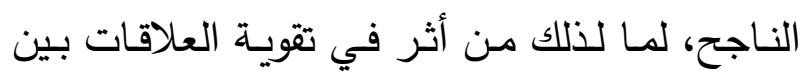

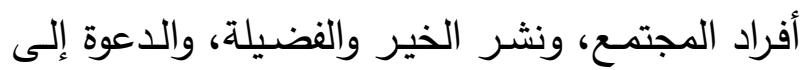
الله بالحكمة والموعظة الحسنة.

هذا وإن أحسنت فمن الله الكريم المنان، وإن أخطأت فمن نفسي والشيطان. وآخر دعوانا أن الحمد الله رب آله

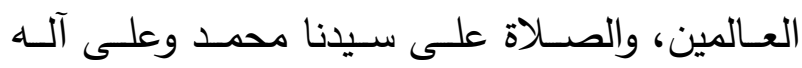
وصحبه وسلم.

\section{قائمة المصادر والمراجع}

*اتحاف الخيرة المهرة بزوائد المسانيد العشرة،أحمد بن أبي بكر بن إسماعيل البوصيري ،المحقق: دار

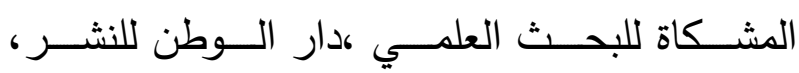

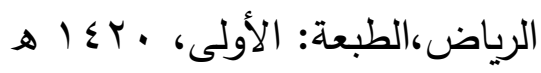


العابـدين المنــاوي ،المكتبـــة التجاريــة الكبـرى ـ

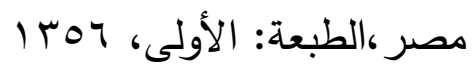

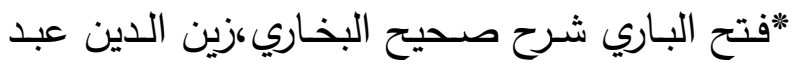

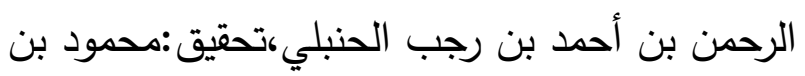

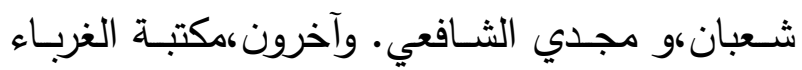

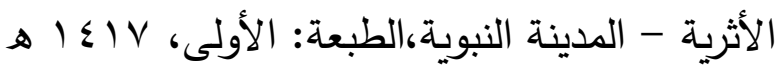

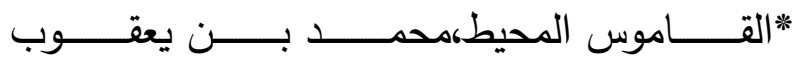
الفيروزآبادى،حقيق: مكتب تحقيق التراث في ليق ليق مؤسســــــة الرسالة،مؤسســــــــة الرســـــــالة -

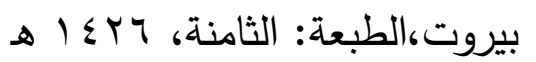

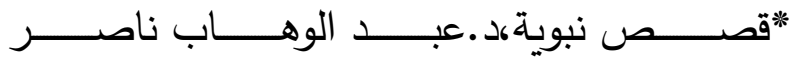

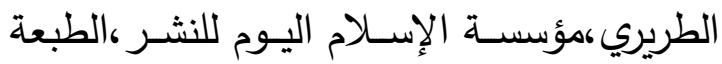

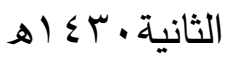

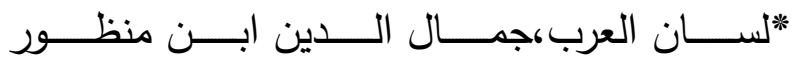
الأنصـاري،دار صـادر - بيروت،الطبعـة: الثالثة ه $1 \leqslant 1 \leqslant$

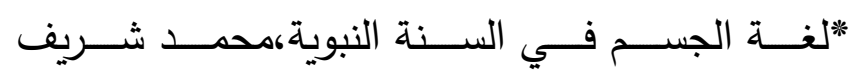
الخطيب،رسالة ماجستير ،الجامعة الأردنية ، ، . . . .

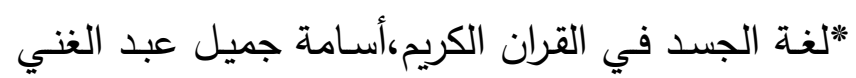

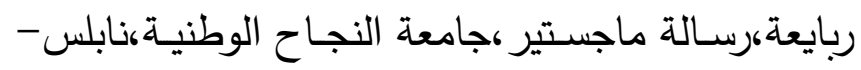

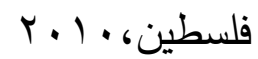
"لغـة الجســ،بيتر كليتون،ترجمـة دار الفـاروق ،دار

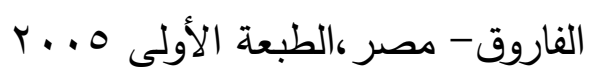

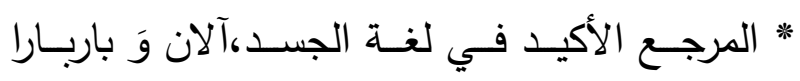

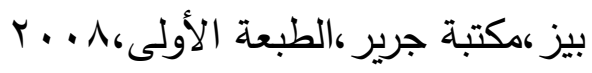

"سنن ابن ماجاهمحمد بن يزيد القزويني، تحقيق:

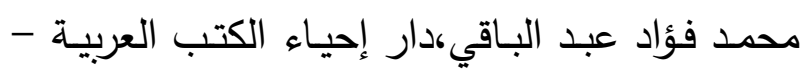
فيصل عيسى البابي الحلبي.

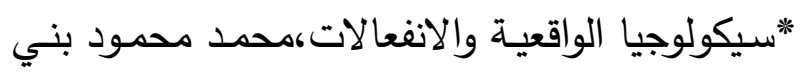

يونس،دار المسيرة-عمان،الطبعة الأولى V...

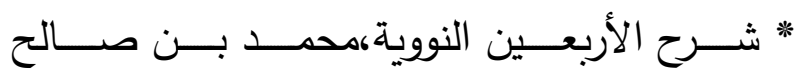

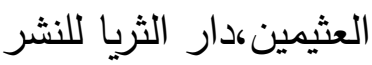
"شرح صحيح البخارى لابن بطال،أبو الحسن علي بن خلف بن عبد الملك ،تحقيق: أبو تميم ياسر بن بن لإل

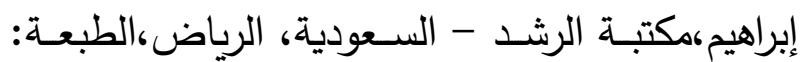

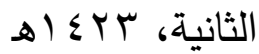

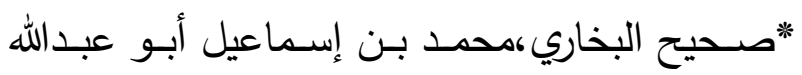
البخـاري الجعفي ،المحقق: محمد زهير بـن ناصـر

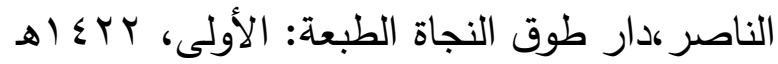

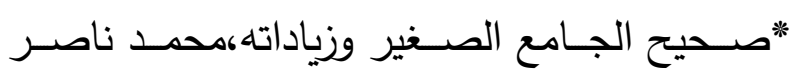
الدين الألباني،المكتب الإسلامي.

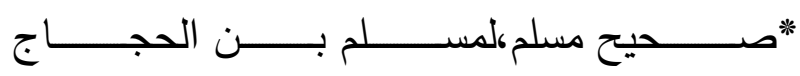
النيسابوري،،،المحقق: محمد فؤاد عبد الباقي،دار إحياء التراث العربي - بيروت *عمـدة القـاري شـرح صــيح البخاري،بــدر الــين العينى محمود بن أحمد بن موسى،دار إحياء التراث العربي - بيروت *فتح الباري شرح صحيح البخاري،أحمد بن علي بن حجر العسقلاني،دار المعرفة - بيروت،

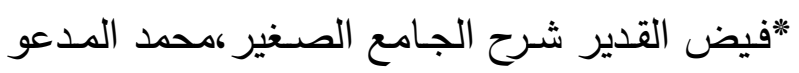
بعبد الـرؤوف بـن تـاج العـارفين بـن علـي بـن زيـن 
"الدنهاج شرح صحيح مسلم بن الحجاج،أبو زكريا. محيي الدين يحيى بن شرف النووي،دار إحياء

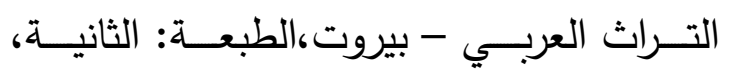

$$
\text { . 1 rar }
$$

*مهـارات الاتصــال ،تحريـر : د. سـعد بـن بركي أمي المسـودي،جامعة الملك عبد العزيـز -جدة،الطبعـة

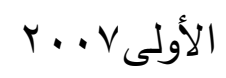

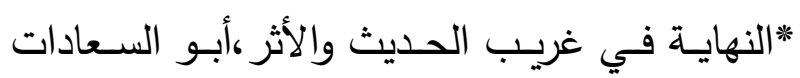

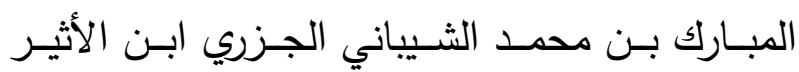

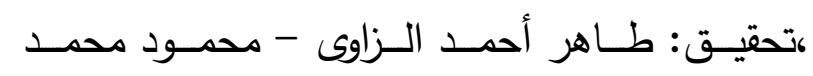

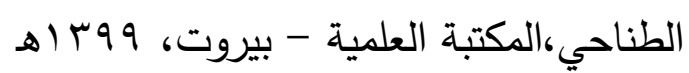

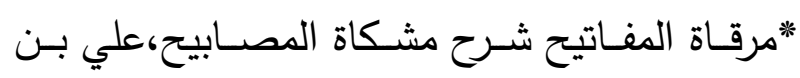

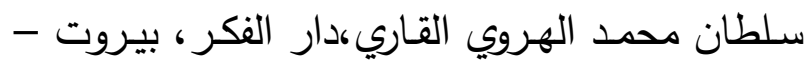
لبنان،الطبعة: الأولى، ب أ الهروي الفاري

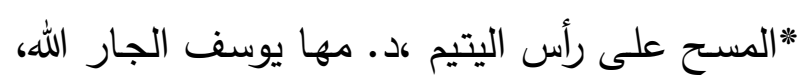
بحث مقدم للمؤتمر العالمي العاشر للإعجاز

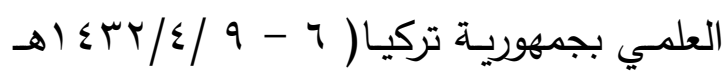

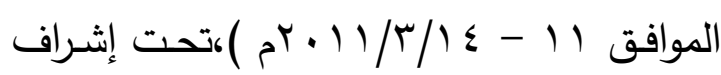
الكيئة العالميـة للإعجاز العلدي في القرآن و السنة. "مسند الإمام أحمد بن حنبل، أبو عبد الله أحمد بن

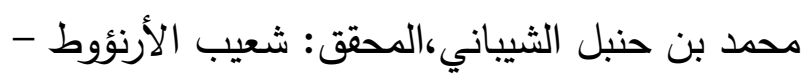

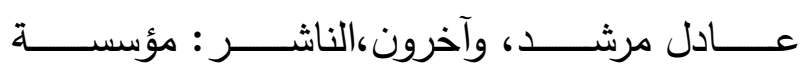

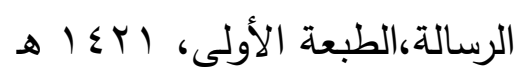

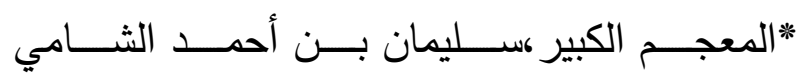

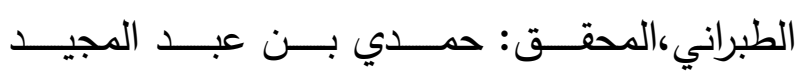
السلفي،مكتبة ابن تيمية القاهرة،الطبعة: الثانية.

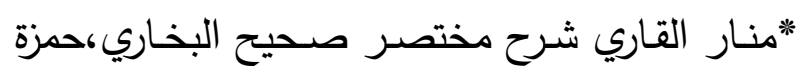

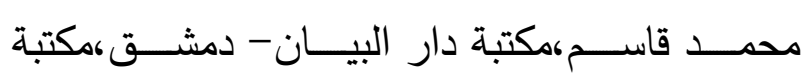

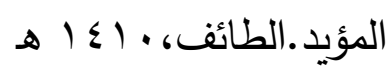


لغة الجسد في السنة النبوية (لغة الأيدي أنموذجا)

\title{
All praise is due to Allah،the Lord of the worlds‘and peace and blessings are upon His Prophet‘Muhammad.
}

\author{
Reem bint Khalid bin Abdullah Alsqaf \\ Faculty of Arts and Humanities \\ Jeddah - Kingdom of Saudi Arabia
}

\begin{abstract}
Prophetic tradition (Sunnah) about communicating through body language. The research's objective: (1) Demonstrating body language in the Prophetic Sunnah. (2) Gathering some hadiths related to body language - hands' language - in the Prophetic Sunnah. (3) Explaining the significance of body language rits benefit and effect of its use together with linking it to reality by referring to the explanations of hadiths and books on communication skills.

In this research'I adopted the inductive and deductive methods. The research's plan was divided into an Introduction'two topics and a conclusion. Topic One dealt with the concept of body language and its importance in communication. Topic Two introduced a model from hadiths that mentioned the hands' language in the Prophetic Sunnah. Then'I provided the Conclusion in which I presented the most important results that I reached; the most notable of which were: (2) Prophetic Sunnah comprised several situations which clarified the use of the language of hands as a means of effective communication‘explaining meanings‘persuading or expressing feelings or kindness. (2) The Prophetic Sunnah has the precedence over modern studies in giving attention to communication skills‘particularly body language.

Among the prominent recommendations were the following:

1- The necessity of benefiting from the Prophetic Sunnah in rooting the science of communication skills. There were many situations in the Prophet's biography that showed his communication with his companions‘which had a significant effect on the teaching educational and social aspects.

2- The need،on the part of researchers'to realize the importance of cognitive integration between the specializations of humanities and of contributing to the research that combines more than one specialization،as this has its effect of rooting knowledge.
\end{abstract}

